\title{
Urinary Stones in Neonates: Dilemma Between Urolithiasis and Nephrocalcinosis
}

\section{Yeni Doğanlarda Üriner Sistem Taş/arı:Ürolitiyazis ve Nefrokalsinozis Ikilemi}

\author{
Fatma Narter1, Fehmi Narter2, Kemal Sarıca2 \\ ${ }^{1}$ Kartal Dr. Lütfi Kırdar Research and Training Hospital, Clinic of Neonatalogy, Istanbul, Turkey \\ 2Kartal Dr. Lütfi Kırdar Research and Training Hospital, Clinic of Urology, Istanbul, Turkey
}

\begin{abstract}
Urinary stones are extremely rare in the neonatal population. Most of the urinary stones in the neonate contain calcium. Nephrolithiasis in the neonate may be as urolithiasis and/or nephrocalcinosis. The incidence of nephrocalcinosis is not yet clear and can be differ in many researches due to the etiology. On the other hand, the incidence of urolithiasis in childhood is almost $10 \%$ of that in adults. Especially in the first decade, it is more common in boys. It may occur with inherited metabolic changes such as hypercalciuria, primary hyperoxaluria or cystinuria. Stone formation can be effected by iatrogenic causes such as hyperalimentation (parenteral nutrition), diuretic therapy (furosemide, acetazolamide) that is especially in the bronchopulmonary dysplasia. The stone formation may occur due to anatomic or functional obstructions and infections of urinary system. Most of the urinary stones in the neonatal period are diagnosed as a nephrocalcinosis. However there aren't any exact differences between nephrolithiasis and nephrocalcinosis. Some authors suggested nephrocalcinosis is the initial step of urinary stone formation. On the other hand, the others purposed that both of them are different pathologies. In this review, we tried to summarized differences and similarities, in the context of urinary stones and the nephrocalcinosis in the neonates.
\end{abstract}

\section{Key Words}

Urinary tract, stone, nephrocalcinosis, urolithiasis, neonatal, newborn

\section{ÖZET}

Üriner sistem taşları neonatal dönemde çok nadirdir. Çoğu yeni doğan idrar yolu taşları kalsiyum içerir. Yeni doğanlarda nefrolitiyazis urolitiyazis ve/veya nefrokalsinozis şeklinde olabilir. Nefrokalsinozisin insidansı henüz net olarak bilinmemektedir ve sebep olan etiyolojiye göre farklı bildirilmektedir. Öte yandan çocukluk çağında idrar yolu taşının insidansı erişkindekinin yaklaşık \%10'u kadardır. Özellikle birinci dekadda erkelerde daha sıktır. Hiperkalsiüri, primer okzalüri veya sistinüri gibi kalıtımsal metabolik değişikliklerle oluşabilir. Taş oluşumu hiperalimentasyon (paranteral beslenme), diüretik tedavi (furosemid, asetazolamid) gibi iyatrojenik sebeplerle özellikle bronkopulmoner displazilerde sık oluşur. Taş oluşumu anatomik veya fonksiyonel obstrüksiyonlar ve enfeksiyonlara ek oluşabilir. Yeni doğan döneminde genelde saptanan nefrokalsinozis bazı araştırmacılar tarafınca idrar yolu taş hastalığının başlangıç aşaması olarak kabul edilse de, öte yandan her iki patolojiyi ayrı kabul eden araştırıcılarda bulunmaktadır. Her iki patolojinin farklııkları ve benzerlikleri net değildir. Biz de bu derlemede nefrokalsinozis ile ürolitiyazis arasındaki ikilemi özetlemeye çalıştık.

\section{Anahtar Kelimeler}

İdrar yolu, taş, nefrokalsinozis, ürolitiyazis, neonatal, yeni doğan

\section{Introduction}

The incidence of urolithiasis in childhood is almost $10 \%$ of that in adults (1). Urolithiasis and nephrocalcinosis are the two types calcification in the urinary tract. Urolithiasis is macroscopic calcification in the urinary collecting system. Urinary stones are composed of lithogenic crystal agglomerations and formed on the renal papillae by adherence to damaged renal epithelium. The imbalance of the activating factors such as high calcium/oxalate excreation and the inhibitor factors such as low citrate excreation determines stone forming. Nephrocalcinosis is microscopic calcification in the tubules, tubular epithelium or interstitial tissue of the kidney. It is classified according to locations are involved such as medullary, cortical or diffuse. Urolithiasis and nephrocalcinosis may occur together or separately. Theoretically, the composition and type (nephrocalcinosis or urolithiasis) of the deposits can be defined most effective with biopsy by pathologists. We summarized features of nephrocalcinosis and urolithiasis in the Table 1.

Prevalence rate of nephrocalcinosis was found 7-64\% with a wide range in in the literature (2-12). Nephrocalcinosis is determined

\section{Correspondence}

Fehmi Narter MD, Kartal Dr. Lütfi Kırdar Research and Training Hospital, Clinic of Urology, İstanbul, Turkey Phone: +90 5324153550 E-mail: fehminarter66@gmail.com Received: 01.02.2015 Accepted: 02.02.2015 
by repeated ultrasonography and may disappear in course of time $(13,14)$. In the long-term studies, spontaneous resolution in course of time of nephrolithiasis for the preterm infants was reported 20$60 \%(8,15-19)$. Nephrocalcinosis will resolve in $75 \%$ of patients at 1-2 years of age. A prospective study suggested a 35\% probability of nephrocalcinosis present at term to persist for at least 15 months and a $15 \%$ probability to persist for at least 30 months (19). It can be persistence among $10-25 \%$ was reported after 7 years $(17,18)$. The long-term datas of nephrocalcinosis in preterm neonates have not been clear. Decreasing of renal function is due to lower gestational age or a lower birth weight was found for patients with nephrocalcinosis at term $(16,20,21)$. Crystallization for nephrocalcinosis is common occur in immature kidneys of preterm infants. This can be explained by the 'heterogeneous nucleation' and 'low glomerular filtration rate' theories. In these theories, heterogeneous nucleation could occur earlier in preterm neonates than in adults and developing of nephron is continious process in this period so that preterm neonates have a low glomerular filtration rate (GFR) in fetal and neonatal life $(17,22)$. Normally, the development of the kidney is centrifugal. Medullary nephrons in the deep develop earlier than the superficial cortical nephrons. Intrauterine growth retardation (IUGR) is associated with oligonephronia but not low birth weight. GFR increases due to development of the number and size of nephrons until the 36th week of gestation and reaches approximately $20 \mathrm{~mL} / \mathrm{min} / 1.73 \mathrm{~m} 2$ at 1 month of age in term. After the this period, GFR increases and reaches adult levels between 1 and 2 years of life. Plasma creatinine is high $(1.1 \mathrm{mg} / \mathrm{dL})$ at birth and then it decreases in the 1st week of life. In preterm infants, serum creatinine increases at 2-4 days of life and then decreases progressively, reaches to $0.4 \mathrm{mg} / \mathrm{dL}$ later and mostly at week 2 to 3 postnatal. Serum creatinine concentration may depend on maturation of the renal tubules (tubular reabsorption or secretion), the total muscle mass of the body and glomerular filtration rate. In the preterm infants, high serum creatinine levels may be depend on maternal serum creatinine (maternal kidney function, hydration, catabolic status, muscle mass), tubular reabsorption, underestimating of the true GFR in very low birth weight neonates with creatinine clearance, laboratory errors in the measurement of the serum creatinine levels (hyperbilirubinemia, hypertryglyceridemia, hemolysis, ketonemia), GFR overestimation (tubular secretion of creatinine or secretion into the intestine), growth in muscle mass, dependence of age and gender, insensitivity of serum creatinine to small changes of GFR. Some reports have been suggested that nephrocalcinosis may predispose to glomerular and tubular dysfunction and the others have been proposed that prematurity alone leads to renal dysfunction. Kidney dysfunction may be depend on asphyx, feeding with formulas (best feeding with human milk), high renal solute load and negative water balance.

\section{Diagnosis}

Nephrocalcinosis seems to appear in the first years of life, which might be due to tubulopathies or metabolic disease of newborn. Nephrocalcinosis does not necessarily lead to renal calculi, nephrocalsinosis and urolithiasis may appear together in the same patient or may occur separately in the apparent absence of (macroscopic) nephrocalcinosis $(23,24)$. Endoscopic examination of papillae may distinguish nephrocalcinosis or microcalculi which may be visualized as a hyperechoic spot of $<3 \mathrm{~mm}$ in diameter on ultrasound or as a stone of a diameter $<2 \mathrm{~mm}$ on a low enhanced computed tomography (CT) (25-27). Nephrocalcinosis are present mainly in the renal medulla. Medullary nephrocalcinosis can only be diagnosed when increased echogenicity appears in the area of the renal medulla by ultrasonography. It can be detected like white dots or white flecks that are echodense pyramids in the kidneys. Normally, the renal pyramids are hypoechoic areas in relation to the cortex. Echogenity can vary from small flecks of 1 to $2 \mathrm{~mm}$, white dots larger than $2 \mathrm{~mm}$, to completely echodense pyramids in the sonography. Two echogenic parallel stripes are considered to be the arcuate or branch arteries. Acoustic shadowing are not very common. For nephrocalcinosis, US was more sensitive than CT (96\% vs. 64\%), but CT was more specific than US (96\% vs. $85 \%)$ in the rabbit research (6). US can use preferably to detect nephrocalcinosis, because it is a noninvasive, no need for sedation and sensitive method that does not involve radiation in infants. By 15 to 17 postmenstrual weeks half of fetal kidneys can be detected and the internal architecture of the kidneys can be reliably assesed on ultrasound examination and by 20 postmenstrual weeks 95\% of fetal kidneys can be visualised. The supine position is suitable for preterm infants and the prone

Table 1. Features of the neprocalcinosis and urolithiasis

\begin{tabular}{|l|l|l|}
\hline FEATURES & Nephrocalcinosis & Urolithiasis \\
\hline Appearance & Microscopic calcification & Macroscopic calcification \\
\hline Location & Tubules, tubular epithelium or interstitial tissue of the kidney & Urinary collecting system \\
\hline Follow-up & May disappear, spontan resolution & Spontan resolution not occur \\
\hline Theroies of etiology & Inmature kidneys and low glomerular filtration rate & Activating and inibitor factors, stone formation theories \\
\hline Risk factors & Prematurity, metabolic, medications, intoxications & Metabolic, medications, intoxications \\
\hline Diagnosis & Hyperechoic spot of $<3 \mathrm{~mm}$ in USG or $<2 \mathrm{~mm}$ on a low enhanced CT & $\begin{array}{l}\text { hyperechoic spot of }>3 \mathrm{~mm} \text { in USG or }>2 \mathrm{~mm} \text { on a low } \\
\text { enced CT }\end{array}$ \\
\hline Symptoms & Mostly asymptomatic & Symptomatic \\
\hline Therapy & Conservative & Conservative or invasive \\
\hline
\end{tabular}


position is the best choice for term newborns on the sonographic evaluation. Generally, image of the newborn kidneys is appeared to be similar or of slightly lower reflectivity than the liver. The best visualisation of the kidneys is obtained during the first few days of life before the child is established on gastric feeds. The other causes of increased medullary echogenicity in the preterm neonate are renal transient medullary hyperechogenicity, candidiasis, cytomegalovirus infection, infantile polycystic kidney disease or renal vein thrombosis. Ultrasonographic findings of transient medullary hyperechogenicity can be found in the first days of life of healthy full-term neonates and disappears within 6 to 14 days $(28,29)$. The etiology of the transient medullary hyperechogenicity is not clear. Some authors suggest that aggregates composed of Tamm Horsfall protein (THP) cause the increased echogenicity. THP deposits within the renal calyces may look like nephrocalcinosis. Furthermore, the echogenicity of the renal cortex in neonates is physiologically increased, hence detection of cortical nephrocalcinosis can be difficult and may become evident only some weeks later when a rim of cortical calcification becomes visible. Cortical nephrocalcinosis is rare in infancy, but is described in acute cortical necrosis, renal vein thrombosis, cystinosis, chronic graft rejection, chronic glomerulonephritis and hyperoxaluria (30-33). Diffuse cortical nephrocalcinosis may already be detectable shortly after birth in patients with suspected primary hyperoxaluria.

\section{Etiopathogenesis}

Molecular mechanisms of stone disease are not clear yet. Stone formation by interstitial apatite plaques (Randall's plaques) on the papillae is typical of idiopathic calcium oxalate stone formers (34), crystal deposition in renal tubules is found in all stone-forming groups. Free solution crystallization is described to be typical of patients with cystinuria or secondary hyperoxaluria. Crystal formation in renal tubules and crystal retention in the distal tubules are main processes for the formation of nephrocalcinosis. Depend on increase of lithogenic factors or decrease of urine volume, urinary supersaturation leads to crystal formation in the renal tubules. If supersaturation does not exceed a certain level and duration, nonadherent epithelium, as well as tubular transport mechanisms controlling urine composition and adding crystal inhibitors such as citrate, magnesium and proteins, allow passage of supersaturated urine as well (35-41). When unhealty damaged epithelium occurs or failure of these protective tubular mechanisms, crystal retention is possible. This takes place in proliferating or regenerating cells in the distal nephron, which luminally express hyaluronan and osteopontin. Crystallization occurs due to proliferating and regenerating cells of preterm kidneys (especially depend on incomplete nephrogenesis, ischemia and nephrotoxic medications). Disrupting of the preventive physiological mechanisms for the crystal formation, adhesion can be occured by high amounts of a soluble crystal due to hyperabsorption (vitamin A/D excess, chronic inflammatory bowel disease, small bowel syndrome), overproduction (primary hyperoxaluria), deranged epithelium (infection, prematurity) and tubular transport defects (tubulopathies). Secondary heterogeneous nucleation of calcium phosphate or oxalate crystals in damaged tubular cells is the similar.
Aetiological factors of urolithiasis/nephrocalcinosis are classified as genetic pathologies, metabolic disorders, anatomical abnormalities, urinary tract infections and environmental factors (obesity, diet, fluid intake, metabolic syndrome) in pediatric patients. Prematurity is the main aetiological factor for nephrocalcinosis. Risk factors of nephrocalcinosis/urolithiasis are hypercalciuria (renal tubular abnormalities, abnormal handling of salt, over-production of prostaglandin E2, abnormal synthesis of 1,25-dihydroxy vitamin D3), primer or seconder (enteric) hyperoxaluria, hypocitraturia, hyperuricosuria, cystinuria, medication-intoxication (loop diuretics, calcium/vitamin D supplementation, carbonic-anhydrase inhibitors, topiramate, ethylene glycol, melamine, indinavir), tumor treatment (steroid treatment, loss of mineral from bone, reduced intestinal and renal calcium absorption) and urinary tract infections (Ureaseproducing bacteria). In the infancy, medullary nephrocalcinosis can develop as a result of renal tubular acidosis, administration of

Table 2. Causes of the renal calcification at neonatal intensive care unit (NICU)

Normocalsemic Hypercalciuric

Distal renal tubular acidosis

Bartter syndrome

Hyperprostaglandin E syndrome

Cushing syndrome

Adrenocorticotrophic hormone therapy for infantile spasms

Long term furosemide theraphy

Idiopathic hypercalcuria

Familial hypomagnesemia

Hypercalcemic Hypercalciuric

Hyperparathyroidism

Subcutaneous fat necrosis

Hypophosphatasia

Williams syndrome

Paraneoplastic Phenomenon

Idiopathic infatile hypercalcemia

Vitamin D intoxication

Normocalsemic Normocalciuric

Primary Hyperoxaluria

Short bowel associated Hyperoxaluria

Renal candidiasis

Rhabdoid tumors of the kidney

Dystrophic calcification

Long term acetazolamide therapy

Melamine contaminated formula 
furosemide, corticosteroid or vitamin D for preventing of rickets, hyperparathyreoidism or hyperoxaluria $(42,43)$. Approximately $80 \%$ of the calcium and phosphorus accumulate in the fetus between the 25th postconceptional week and full term, with a peak between 34 and 36 weeks.

In the context of genetic factors, as neonates with a positive family history of kidney stones, those of male gender, and those of Caucasian race are more likely to develop nephrocalcinosis $(9,10,44)$. Approximately $40 \%$ of children with urolithiasis have a positive family history, and most of the children have a metabolic factor of stone disease. Therefore, metabolic evaluation is necessary for neonates as older children (Table 2).

Risk factors for nephrocalcinosis in the neonatal period include low gestational age ( $<32$ weeks), low birth weight $(<1.5 \mathrm{~kg})$, furosemide, dexamethasone, xanthines (theophylline, caffeine), aminoglycoside, male sex, length of assisted ventilation and oxygen therapy, length of hospital stay, nutrients (formulas and parenteral feeding) and fluid intake. High intake calcium, phosphorus, vitamin D, protein and ascorbic acid in the first four weeks are very important. Aminoglycoside therapy was also reported to contribute to renal calcification in preterm neonates $(2,10,15)$. Premature kidneys have a long loop of Henle and hence a low urine velocity, resulting in crystal aggregation in the tubules (2). Nephrocalcinosis has been clearly associated with low gestational age and birth weight in many sutdies $(4-7,10,44,45)$. Gimpel found a 1.65 fold increased risk per $100 \mathrm{~g}$ lower birth weight (44). Furosemide therapy with $410 \mathrm{mg} / \mathrm{kg}$ body weight per day was the strongest risk factor increasing the risk of nephrocalcinosis about the factor (45). Some studies identified furosemide therapy as a major risk factor, whereas others did not $(4,10,11,46)$. The reduction of passive calcium reabsorption normally driven by sodium chloride transport leads to hypercalciuria and may be aggravated by a slower plasma clearance $(47,48)$. Hypercalciuria itself was reported to increase the risk of nephrocalcinosis about 4.5 times per $\mathrm{mmol} / \mathrm{l}$ increase of urinary calcium concentration. Hypercalcuria in preterm infants has also been associated with high dose steroid treatment, whereas other studies did not identify this as a risk factor $(10,44,46,49)$.

The patients with nephrocalcinosis developed chronic lung disease (CLD) significantly more often. Both of metabolic and respiratory acidosis occur commonly in preterm infants, and risk of renal calcification is very high in the neonatal period. They are generally more immature and often need more of the etiological medications. Preterm infants with lung disease are reported to have decreased urinary citrate, which may predispose them to nephrocalcinosis. It was suggested infants who still required oxygen treatment in the neonatal period, had major risk for renal calcification. Ezzedeen et al. have reported oliguria ( $<1-5 \mathrm{ml} / \mathrm{kg} /$ hour) as a risk factor for renal calcification, found in 59\% of their cases (21).

\section{Therapy}

Nephrocalcinosis is mostly asymptomatic but it is thought to predispose to urinary tract infection, renal colic, irritability and haematuria. If renal stones detected by ultrasonography, early postnatal evaluation is necessary to exclude obstructive lesions. If stones are prenatally detected, and solute/creatinine ratios and 24-hour urine collections can be made so that early diagnosis and specific therapy can be initiated. Early treatment with reducing urinary saturation of the soluble by increasing fluid intake and by providing crystallization inhibitors, as well as disease-specific medication, are mandatory to prevent recurrent kidney stones and/ or progressive nephrocalcinosis, and consequently deterioration of renal function. Conservative therapy by increasing fluid intake and decrease sodium intake using low-sodium formulas are the first choice for neonatal urinary stone disease. Thiazide therapy and magnesium supplementation may be helpful in preventing further stone formation and may dissolve present stones. If there are multiple stones, a trial of potassium citrate should be undertaken. If 1,25-hydroxyvitamin D is elevated and urine phosphate is low, a trial of phosphorous supplementation is reasonable. This is designed to decrease hydroxylation of vitamin D and to decrease calcium absorption and excretion, thereby decreasing stone risk. If patient has normal urinary calcium/creatinine ratio and stone present, urine ratios for cystine/creatinine and oxalate/creatinine have to be check. If elevated oxalate excretion, it can be confirmed with a 24-hour urine collection for creatinine, oxalate, and calcium and obtain a random urine sample for creatinine, glycolate and glycerate. At this time, we can begin a trial of pyridoxine ( 250 to $300 \mathrm{mg} / \mathrm{m} 2$ ). Continue therapy until the results have confirmed or excluded hyperoxaluria. If oxalate excretion is elevated and there is no response to therapy, consider liver biopsy to elucidate the type of hyperoxaluria. Primary risks of urinary stone are recurrence, enlargement of current stone, obstruction, acute or chronic pyelonephritis in neonates. Extracorporeal shockwave lithotripsy (ESWL) is becoming the first treatment of choice in most cases, but this generally involves older children. Surgical management, endoscopic removal are rarely needed in the neonate.

More research is needed to elucidate aetiological factors, longterm effects and possible prevention or cure of nephrocalcinosis in preterm neonates. Long-term follow-up of blood pressure and renal function of prematurely born children, especially with neonatal nephrocalcinosis, seems warranted. Future research pertaining to prevention of nephrocalcinosis in preterm neonates is needed. After the delivery, newborn has to be checked with sonography as soon as posible, and after the first evaluataion periodically newborn has to be follow up for urinary stone disease. The etiology of nephrocalcinosis and long-term effects are not clear as yet, but some small studies show decreased estimated glomerular filtration rate. Nephrocalcinosis in the preterm neonates has been reported frequently and small studies suggest an unfavourable effect on renal function. Finally, urinary stones in neonates is dilemma between urolithiasis and nephrocalcinosis. There is need more researches and following studies about this topic.

\section{Conflict of interest}

There are no conflicts of interest.

\section{References}

1. Habbig $\mathrm{S}$, Beck BB, Hoppe B. Nephrocalcinosis and urolithiasis in children. Kidney International 2011;80:1278-1291. 
2. Schell-Feith $E_{1}$ Kist-van Holthe J, van der Heijden A. Nephrocalcinosis in preterm neonates. Pediatr Nephrol 2010;25:221-230.

3. Schell-Feith EA, Holscher HC, Zonderland HM, Kist-Van Holthe

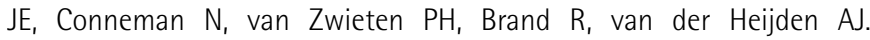
Ultrasonographic features of nephrocalcinosis in preterm neonates. $\mathrm{Br} \mathrm{J}$ Radiol 2000;73:1185-1191.

4. Hoppe B, Duran I, Martin A, Kribs A, Benz-Bohm G, Michalk DV, Roth B. Nephrocalcinosis in preterm infants: a single center experience. Pediatr Nephrol 2002;17:264-268.

5. Jacinto JS, Modanlou HD, Crade M, Strauss AA, Bosu SK. Renal calcification incidence in very low birth weight infants. Pediatrics 1988;81:31-35.

6. Short A, Cooke RW. The incidence of renal calcification in preterm infants. Arch Dis Child 1991;66:412-417.

7. Sheu JN, Chen $\mathrm{CH}_{1}$ Lue KH, Chen JY, Tsau YK, Chen JH. Renal calcification in very low birth weight infants. Am J Nephrol 1993;13:6-11.

8. Saarela T, Vaarala A, Lanning P, Koivisto M. Incidence, ultrasonic patterns and resolution of nephrocalcinosis in very low birthweight infants. Acta Paediatr 1999;88:655-660.

9. Karlowicz MG, Katz ME, Adelman RD, Solhaug MJ. Nephrocalcinosis in very low birth weight neonates: family history of kidney stones and ethnicity as independent risk factors. J Pediatr 1993;122:635-638.

10. Narendra A, White MP, Rolton HA, Alloub ZI, Wilkinson G, McColl JH, Beattie J. Nephrocalcinosis in preterm babies. Arch Dis Child Fetal Neonatal Ed 2001;85:207-213.

11. Hein G, Richter D, Manz F, Weitzel D, Kalhoff H. Development of nephrocalcinosis in very low birth weight infants. Pediatr Nephrol 2004;19:616-620.

12. Ketkeaw K, Thaithumyanon $P$, Punnahitananda S. Nephrocalcinosis in very low birth weight infants: a single center experience. J Med Assoc Thai 2004;87:72-77.

13. Pope IV JC, Trusler LA, Klein AM, Walsh WF, Yared A, Brock JW 3rd. The natural history of nephrocalcinosis in premature infants treated with loop diuretics. J Urol 1996;156:709712.

14. Auron A, Alon US. Resolution of medullary nephrocalcinosis in children with metabolic bone disorders. Pediatr Nephrol 2005;20:1143-1145.

15. Sikora P, Roth B, Kribs A, Michalk DV, Hesse A, Hoppe B. Hypocitraturia is one of the major risk factors for nephrocalcinosis in very low birth weight (VLBW) infants. Kidney Int 2003;63:2194-2199.

16. Jones $C A$, King $S$, Shaw NJ, Judd BA. Renal calcification in preterm infants: follow up at 4-5 years. Arch Dis Child Fetal Neonatal Ed 1997;76:185189.

17. Kist-van Holthe JE, van Zwieten $\mathrm{PH}$, Schell-Feith EA, Zonderland $H M_{\text {, }}$ Holscher HC, Wolterbeek R, Veen S, Frolich M, van der Heijden BJ. Is nephrocalcinosis in preterm neonates harmful for long-term blood pressure and renal function? Pediatrics 2007;119:468-475.

18. Porter E, McKie A, Beattie TJ, McColl JH, Aladangady N, Watt A, White MP. Neonatal nephrocalcinosis: long term follow up. Arch Dis Child Fetal Neonatal Ed 2006;91:333-336.

19. Schell-Feith EA, Kist-van Holthe JE, van Zwieten PH, Zonderland HM, Holscher HC, Swinkels DW, Brand R, Berger HM, van der Heijden BJ. Preterm neonates with nephrocalcinosis: natural course and renal function. Pediatr Nephrol 2003;18:11021108.

20. Downing GJ, EgelhoV JC, Daily DK, Alon U. Furosemide related renal calcifications in the premature infant: a longitudinal ultrasonographic study. Pediatr Radiol 1991;21:563-565.

21. Ezzedeen F, Adelman RD, Ahlfors CE. Renal calcifications in preterm infants: pathophysiology and long-term sequelea. J Pediatr 1988;113:532-539.

22. Kistner $A_{1}$ Celsi G, Vanpee $M$, Jacobson SH. Increased blood pressure but normal renal function in adult women born preterm. Pediatr Nephrol 2000;15:215-220.

23. Alon US. Nephrocalcinosis. Curr Opin Pediatr 1997;9:160-165.
24. Sayer JA, Carr G, Simmons NL. Nephrocalcinosis: molecular insights into calcium precipitation within the kidney. Clin Sci (Lond) 2004;106:549561.

25. Evan AP, Lingeman J, Coe $F$, Shao $Y$, Miller N, Matlaga B, Phillips $C$, Sommer A, Worcester E. Renal histopathology of stone-forming patients with distal renal tubular acidosis. Kidney Int 2007;71:795-801.

26. Polito C, Iolascon G, Nappi B, Andreoli S, La Manna A. Growth and bone mineral density in long-lasting idiopathic hypercalciuria. Pediatr Nephrol 2003;18:545-547.

27. Miller NL, Humphreys MR, Coe FL, Evan AP, Bledsoe SB, Handa SE, Lingeman JE. Nephrocalcinosis: re-defined in the era of endourology. Urol Res 2010;38:421-427.

28. Holland PC, Wilkinson AR, Diez J, Lindsell DR. Prenatal deficiency of phosphate, phosphate supplementation, and rickets in very low birthweight infants. Lancet 1990;335:697-701.

29. Short A, Shaw NJ, Weindling AM. Nephrocalcinosis and phosphate supplementation in a preterm infant. Acta Paediatr Scand 1990;79:968969.

30. Bennett WM,Plamp CE, Gilbert DN, Parker RA, Porter GA. The influence of dosage regimen on experimental gentamicin nephrotoxicity: dissociation of peak serum levels from renal failure. J Infect Dis 1979;140:576-580.

31. Bhatt-Mehta $V$, Schumacher RE, Faix RG, Leady M, Brenner T. Lack of vancomycin-associated nephrotoxicity in newborn infants: a casecontrol study. Pediatrics 1999;103:48.

32. Fauconneau $B$, Favreliere $S$, Pariat $C$, Génévrier $A$, Courtois $P$, Piriou $A$, Bouquet $S$. Nephrotoxicity of gentamicin and vancomycin given alone and in combination as determined by enzymuria and cortical antibiotic levels in rats. Renal Failure 1997;19:15-22.

33. Adams ND, Rowe JC. Nephrocalcinosis. Clin Perinatol 1992;19:179-195.

34. Randall A. The origin and growth of renal calculi. Ann Surg 1937;105:10091027

35. Vervaet BA, Verhulst A, D Haese PC, De Broe ME. Nephrocalcinosis: new insights into mechanisms and consequences. Nephrol Dial Transplant 2009;24:2030-2035.

36. Asplin JR, Parks JH, Coe FL. Dependence of upper limit of metastability on supersaturation in nephrolithiasis. Kidney Int 1997;52:1602-1608.

37. Ryall RL, Fleming DE, Grover PK, Chauvet M, Dean CJ, Marshall VR. The hole truth: intracrystalline proteins and calcium oxalate kidney stones. Mol Urol 2000;4:391-402.

38. Verhulst $A$, Asselman M, Persy VP, Schepers MS, Helbert MF, Verkoelen CF, De Broe ME. Crystal retention capacity of cells in the human nephron: involvement of CD44 and its ligands hyaluronic acid and osteopontin in the transition of a crystal binding- into a nonadherent epithelium. J Am Soc Nephrol 2003;14:107-115.

39. Asselman M, Verhulst A, De Broe ME, Verkoelen CF. Calcium oxalate crystal adherence to hyaluronan-, osteopontin-, and CD44-expressing injured/ regenerating tubular epithelial cells in rat kidneys. J Am Soc Nephrol 2003;14:3155-3166.

40. Verhulst $A$, Asselman $M$, De Naeyer $S$, Vervaet BA, Mengel $M$, Gwinner W, D'Haese PC, Verkoelen CF, De Broe ME. Preconditioning of the distal tubular epithelium of the human kidney precedes nephrocalcinosis. Kidney Int 2005;68:1643-1647.

41. Verkoelen $C_{F}$, Van Der Boom BG, Romijn JC. Identification of hyaluronan as a crystal-binding molecule at the surface of migrating and proliferating MDCK cells. Kidney Int 2000;58:1045-1054.

42. Parsons PP, Garland HO, Harpur ES, Old S. Acute gentamicin-induced hypercalciuria and hypermagnesiuria in the rat: dose-response relationship and role of renal tubular injury. Br J Pharmacol 1997:122:570-576.

43. Frame PT, Phair JP, Watanakunakorn C, Bannister TW. Pharmacologic factors associated with gentamicin nephrotoxicity in rabbits. J Infect Dis 1977;135:952-956. 
44. Gimpel $C$, Krause A, Franck P, Krueger M, von Schnakenburg C. Exposure to furosemide as the strongest risk factor for nephrocalcinosis in preterm infants. Pediatr Int 2010;52:51-56.

45. Blanchard A, Vargas-Poussou R, Peyrard S, Mogenet A, Baudouin V, Boudailliez B, Charbit M, Deschesnes G, Ezzhair N, Loirat C, Macher $M A$, Niaudet $P$, Azizi $M$. Effect of hydrochlorothiazide on urinary calcium excretion in dent disease: anuncontrolled trial. Am J Kidney Dis 2008;52:1084-1095.

46. Schell-Feith EA, Kist-van Holthe JE, Conneman $\mathrm{N}$, van Zwieten $\mathrm{PH}$, Holscher HC, Zonderland HM, Brand R, van der Heijden BJ. Etiology of nephrocalcinosis in preterm neonates: association of nutritional intake and urinary parameters. Kidney Int 2000;58:2102-2110.

47. Mirochnick MH, Miceli JJ, Kramer PA, Chapron DJ, Raye JR. Furosemide pharmacokinetics in very low birth weight infants. J Pediatr 1988;112:653-657.

48. Peterson RG, Simmons MA, Rumack BH, Levine RL, Brooks JG. Pharmacology of furosemide in the premature newborn infant. J Pediatr 1980;97:139-143.

49. Cranefield DJ, Odd DE, Harding JE, Teele RL. High incidence of nephrocalcinosis in extremely preterm infants treated with dexamethasone. Pediatr Radiol 2004;34:138-142. 